\title{
Lampanah Local Tall-A High Yielding Variety for Replanting Coconut in Tsunami Affected Aceh Province Area
}

\author{
Hengky Novarianto $^{1)}$, Ismail Maskromo ${ }^{1)}$, Meity Tulalo ${ }^{1)}$, Jeanette Kumaunang ${ }^{1)}$, Sukmawati \\ Mawardi $^{1)}$ and Emy Sulistyowati ${ }^{2}$
}

\begin{abstract}
Aceh province is one of major coconut producing areas in Indonesia. In 2013 coconut areas in Aceh province was 107,654 ha in which total production of copra was equivalent to 63,743 tons. The entire coconut area in Aceh belong to smallholders. The coconut production in this area began to decrease in 2005 by an average of 9 percent per year, which was mainly caused by the tsunami. This had resulted in damage to many crops. Efforts to increase production and productivity of coconut plantation in Aceh needed rejuvenation of the old or unproductive coconut palms with the use of seeds of improved quality. Based on the results of the research conducted during 2014-2016, it is known that the origin of the Lampanah tall is passed from generation to generation and is a native of coconut in Aceh Besar Regent, Aceh Province. The morphology of Lampanah tall coconut comprising of the crown of leaves, stems, flowers and fruits in general is quite uniform. Of the data on the 23 quantitative characters, all have a value of coefficient of variance below $20 \%$, except the character of 11 leaf scars obtained $23.29 \%$. In the case of polar girth, Lampanah tall coconut is generally greater than the equatorial girth, fruit shape classified as round, egg-shaped and elliptic. The seednut of Lampanah tall generally round shape. The Lampanah tall coconut has the number of bunches at $13.35 / \mathrm{palm}$ and the number of fruit at 9.25 fruits/bunch or an average of 138 fruits/palm/ year. Fresh coconut meat weight is $449 \mathrm{~g} / \mathrm{nut}$ or approximately $224 \mathrm{~g}$ copra/nut and the potential for copra production was 30.97 $\mathrm{kg} / \mathrm{palm} /$ year or 3.80 tons of copra/ha/year. The fat content of Lampanah tall coconut was $66.40 \%$, the water content of copra approximately $3.42 \%$ and protein at approximately $6.81 \%$. Total saturated fatty acids was at $94.27 \%$, medium chain saturated fatty acids at $67.21 \%$ and lauric acid content at $46.50 \%$. The seed source of Lampanah tall coconut has been a selection of as much as 72 Selected Mother Palms (MAS) from a total of 407 palms of the High Yielding Block. The selected population is characterised with traits like copra yield more than 2.0 ton/ha/year, free from attack pests and diseases, number of bunch more than 12 per year, total nuts more than 7/bunch and weight of meat more than $400 \mathrm{~g} / \mathrm{nut}$. The MAS of Lampanah tall whole coconut has been marked using GPS. The Aceh government will build a minimum of 5 ha Coconut tall Seed Gardens on government land, as the development of source of Lampanah tall seednuts. Based on the above results, it can be concluded that the Lampanah tall coconut with plenty of nuts, at an average of 138 nuts per palm could be released as one of the national high yielding coconut.
\end{abstract}

Key words: Tall coconut, variety, morphology characters, fruit component, copra yield, selected mother palm, seed resources.

Note:

1) Breeding researchers in Indonesian Palma Crops Research Institute, Manado.

2) Breeding researcher in Indonesian Fibre and Tobacco Research Institute, Malang.

IPCRI, Raya Mapanget Street, PO.Box 1005, Manado 95001, North Sulawesi, Indonesia.

Telp: 62-431-8120430; Fax: 62-431-8120017; Email: balitka05@yahoo.com 


\section{Introduction}

Coconut palm is one of the strategic plantation crops that play a role in public life, because all parts of the coconut palm can be utilized to meet the economic, social and cultural needs of the society. The total acreage under coconut palm in Indonesia in 2013 is approximately 3.6 million hectares with a production of 3.2 million tons of copra, of which more than $98 \%$ is cultivated by smallholder plantations spread almost throughout the territory of Indonesia. The Aceh Province is one of the main coconut producing region in Indonesia. The data from the statistical books on plantation by Directorate General of Plantation in 2013 showed that coconut plantation in Aceh province is 107,654 ha with a total production of 63,743 tons of equivalent copra mainly cultivated in people's estates. (Direktorat Jenderal Perkebunan, 2014).

The potential production of coconut in Aceh Province has decreased in all terms ie., by total area, harvested area, production and the potential of coconut production. Based on Data of Statistic Center Board from 2005 to 2009, 128,024 ha of coconut plantation area and production of 90,708 tons in 2005 decreased to 101,751 ha and 56,875 tons in 2009. Extensive decline of coconut plantation and coconut production is mainly caused by the tsunami which resulted in damage to many crops. Efforts taken to rehabilitate the plantations are inadequate to increase production and productivity of coconut in a short time and since 2005 , the coconut production in this area has decreased by an average of 9 percent per year with an estimated 33,833 tonnes (Romano, 2013).

To improve and increase the production and productivity of coconut plantation in the province of Aceh, the rejuvenation and expansion of coconut palms is necessary, whose implementation requires superior coconut seedlings. As the availability of superior coconut seed is still limited at national level and transportation from other areas would incur a very large cost, the strategy used so far is to utilize good local tall material of coconuts from high yielding block in that region. Associated with it, in 2014, the Agriculture Agency of Aceh Province in collaboration with Indonesian Palm Crops Research Institute (IPCRI), Agency for Agricultural Research and Development (AARD) undertook assessment and determination of High Yielding Block (HYB) and the Mother Palm Selected (MAS) in December 2014 in Lampanah site, the Region of Aceh Besar. The observations and results from Ujong Keupula Village, Seilimeun district, Aceh Besar regency suggests that the coconut high yielding block has a production potential of about 3.02 tons of copra / ha / year. Novarianto and Tenda (2002) reported that high-yielding varieties of coconut Mapanget tall, Tenga tall, Bali tall and Palu tall has a potential yield of about 2.8 tons - 3.3 tons of copra / ha / year. After observation, it was found that population of Lampanah local tall has potential production of copra up than 3.0 ton/ha/year and the IPCRI suggested to leader of Estate Crops in Aceh to continue research activity to that High Yielding Block and can be released as National Variety.

This research was aimed to develop a superior variety and release from Lampanah Tall coconut which can become a source of seed nuts to support the rejuvenation of coconut in the Province of Aceh, where most of the coconut palms have been damaged by the tsunami on 26 December 2004. To identify the superior palms, observations on the morphological data, production, fruit components, selection of mother palms, fat content and fatty acid composition of Lampanah Tall coconut were recorded.

\section{Materials and Methods}

Observations were taken on Lampanah Tall coconut in Lampanah site, Keupula Ujong village, Seilimeum District, Aceh Besar Region, Aceh Province. Observations were recorded from 2014 till 2016 among the palms in the village of Ujong Keupula Lampanah which is about $56 \mathrm{~km}$ from the province of Banda Aceh. Lampanah tall coconut plantations are owned by the local community and has grown old and is hereditary. 


\section{Assessment and Determination of High Yielding Block (HYB)}

Block is a coconut plantation whose crops are in one plot (not scattered) with an area of at least 2.5 ha and a maximum of 25 ha. Requirements of plant populations to be used as seed source block must fulfill the technical criteria as follow:

a. Age of plants at least 15 years and a maximum of 60 years.

b. Production of at least 2.0 tons of copra / ha / year for local Tall coconut

c. Coefficient of variance of character especially fruit component character is less than or equal to $20 \%$.

d. Free from pests and diseases of coconut.

e. Block coconut plantation located in the strategic area so that it is reachable.

Information about a, d, and e is obtained through direct observation visually in field, while the criteria $b$ and $c$ were based on the observation and analysis on diversity of primary data on the morphology of crops and number of fruit and nut components. Determination of sample palm is done randomly by a diagonal or leap system. The number of sample trees for each block was at least 30 trees according to Stantech COGENT (Santos et al., 1997). The sample trees were determined as follows:

Observation of morphological characters that include vegetative, generative, production and fruit components. Characters vegetative and generative observed are:

a. Stem morphology : Girth measurement (cm) above soil level at $20 \mathrm{~cm}$, girth measurement at $1.5 \mathrm{~m}$ height $(\mathrm{cm})$, length $(\mathrm{cm})$ of stem with 11 leaf scars, measurement starting from the bottom of the first leaf scar to the bottom of the 11 leaf scar;

b. Leaves: Shape of crown, colour of petiole, number of leaf, raches length $(\mathrm{cm})$, petiole length $(\mathrm{cm})$, petiole width $(\mathrm{cm})$, petiole thickness $(\mathrm{cm})$, number of leaflets, length $(\mathrm{cm})$ and leaflet width $(\mathrm{cm})$; c. Inflorescence and Flower morphology: number of bunches, length of peduncle $(\mathrm{cm})$, length $(\mathrm{cm})$, length of central axis $(\mathrm{cm})$, peduncle width $(\mathrm{cm})$, peduncle thick $(\mathrm{cm})$, number of spikelet and number of female flower;

d. Fruit appearance: number of fruits, fruit colour (less than 8 months old), shape of fruit polar and equatorial view, and shape of husked nut;

e. Fruit Component Analysis (FCA): Fruit weight $(\mathrm{g})$, Nut weight $(\mathrm{g})$, Weight of split nut $(\mathrm{g})$, shell weight $(\mathrm{g})$ and meat weight (g);

f. Component of Production:

- Number of bunches/palm by counting beginning from the fully open bunches until the bunches from the sequence bunches.

- Number of nuts/palm/year namely the number of bunches/year multiplied by the number of nuts/bunches.

- Weight of nut, dehusked nut and fruit components is the average weight of the 30 nuts of sample from 30 sample palms, and fruits is weighed and measured fruit component one by one.

Data processing was conducted to determine the average, standard deviation (SD) and the coefficient of variance $(\mathrm{CV})$ using the observed data on different characters: fruit weight, nut weight, weight of split nut, shell weight, meat weight, number of fruits/bunch, number of fruits/palm/year (Comstock et al., 1963; Tampake, 1987):

\section{Mother Palm Selected (MAS) as Seednuts Resource.}

Characters were observed during selection of the Mother Palm Selected, namely :

a. Crown shape is spherical or semispherical,

b. The number of leaf over 29 leafs at the crown, 
c. Petiole Short and wide, so sturdiness sustains the fruits,

d. Short and stumpy bunches,

e. There are no empty fruit bunches,

f. Produces at least 12 bunches/year with an average of 7 nuts/bunches,

g. Meat weight above $400 \mathrm{~g} / \mathrm{nut}$,

h. The nut shape of a round, egg-shaped or pearshaped,

i. Nut shape of round, angular or flat,

j. $\quad$ Not attacked by pests and diseases. (Note: Entomology and Phytopathology divisions of IPCRI led by Prof. Dr. Meldy Hosang and Mr. Arie Lolong undertook observations and collected data to know the level of attack by pests or diseases in Lampanah Tall in 2016.)

Whole MAS which have been selected based on these criteria and then labeled.

\section{Analysis of Fat Content and Fatty Acid Content}

Analysis of fat content, fatty acid content and fatty acid composition of Lampanah Tall coconut oil using test methods/techniques; SNI 01-2891-1992, item 8.2 by means of GC (MU / INST / 1) (Analysis has been undertaken directly from Laboratory in Bogor, Indonesia).

\section{Result and Discussion}

\section{Origin of Lampanah Tall Coconut}

The results of discussions and interviews with the coconut farmers in Lampanah Block, Ujong Keupula village, District Seilimeum, Aceh Besar Regent about the Lampanah Tall coconut origin, revealed that the Lampanah Tall coconut has been inherited ever since earlier times. The results of visual observation of the appearance and production of Lampanah Tall coconut showed sufficiently uniform population growth, with a regular spacing about $8 \times 8$ meters on all coconut plantations in Lampanah Block. In general, coconut plantations owned by farmers in Indonesia are observed to be under irregular spacings with many coconut inserts of various age levels. Whereas in Lampanah palm that grows along the coast overlooking the Indian Ocean, the area below the coconut is fairly clean. Results of interviews with plantation owners revealed the fact that coconut planted in the garden is cultivated by their parents and inherited and not as a result of government projects such as the CWC or PRPTE (project of rehabilitation and expansion of export crops). Estimated age of the studied Lampanah Tall coconut is around 50 years.

Based on observations and interviews with the owners of the coconut, it can be concluded that the origin of the Lampanah Tall coconut were based on the process of selection and further handed down from one generation to the next and is thus an authentic coconut of Aceh Besar Region.

\section{Assessment and Determination of Lampanah Tall coconut High Yielding Block}

Evaluation and determination of High Yielding Block (HYB) coconut in Lampanah Block, Ujong Keupula village, Seilimeum district, Aceh Besar Regent was conducted in 2014. The spacing between palms is very organized about $8 \times 8$ meters. The existence of important pests and diseases in coconut and damage caused to the sample trees by pests Oryctes rhinocerus, Rhynchoporus ferrugineus, Brontispa longissima and bud rot disease caused by Phytopthora palmivora were also observed in the study area.

The High Yielding Block (HYB) palms were find to visually show sufficiently uniform growth and were healthy and do not indicate the presence of pests and diseases, both in the leaves, the crown of leaves, shoots, the flowers and coconuts. Spacing between plants approximately $8 \times 8$ meters, or about 150 trees / ha. It was observed among the coconut crops that there is no intercropping with other plants or shrubs, but only grow some types of weeds or grass. The layout of the coconut population near the coast was studied and it is estimated to be approximately 2-4 m height above sea level. The soil is of sandy alluvial types and looked quite loose and fertile. 
The observations on the production and the fruit components of HYB Lampanah Tall coconut are presented in Table 1. The results of the analysis showed that the population of Lampanah Tall coconut produces an average of 13.23 bunches / palm, the number of fruit at 8.76 nuts/bunch, and 117 nuts/palm/year, the weight of nut at $1,374 \mathrm{~g} / \mathrm{nut}$, weight of dehusked nut at $900 \mathrm{~g} / \mathrm{nut}$ and the weight of endosperm at 419 g/nut.

Based on this observation data, it can be estimated potential production of copra is $117 \mathrm{x}$ $210 \mathrm{~g}=24.57 \mathrm{~kg} / \mathrm{palm} /$ year, or if multiplied by 123 trees per hectare (spacing $9 \times 9$ meters), potential production of copra obtained 3.02 tonnes/ha/year. All the characters in Table 1 can be seen to show a value of $\mathrm{CV}$ above $20 \%$, except number of bunches/palm. Thus, there is an opportunity to make the selection of mother palm selected based on the character of production in order to increase the productivity of Lampanah Tall coconut derivatives.

Assessment and determination of High Yielding Block (HYB) is based on production potential of the population, i.e. at least above 2.0 tons of copra / ha / year to be defined as HYB (Note: This is not a general standard, but a standard for Indonesia only) and furthermore selected and assigned Mother Palm Selected (MAS) as a source of improved seed high yielding of local tall. But if the results of the evaluation gives a copra production potential of over 3.0 ton/ha /year, the coconut population can be recommended to be observed for stability of the results for three years continuously, and if steady production is shown, it can be proposed as a candidate for a superior coconut varieties. The results of observations of the Lampanah Tall coconut of Aceh Besar district appeared to have potential copra above 3.0 ton/ha/year, and was then immediately followed by the observation of production and fruit components in MAS that have been selected as a source of seeds and then observed until 2016. Results of other studies indicate that the selection of $5 \%$ of the crop that has the highest weight of dehusked nut, could increase the weight of dehusked nut weight by $14.4 \%$ in the descendant population (Liyanage, 1973). Furthermore the selection of $10 \%$ and
$15 \%$, can contribute to the increase in weight of dehusked nut respectively by $10.1 \%$ and $7.9 \%$ (Liyanage, 1973).

The different seed resources of high yielding local tall and the local tall as a variety only can distribute the seednuts at local area, meanwhile the seednuts of a coconut variety could be distributed in national areas.

\section{Morphological diversity of Lampanah Tall Coconut}

Observation on morphological characters of Lampanah Tall coconut has been carried out on 30 MAS sample, starting from the characteristics of the stem, crown, leaves, generative to the character of production (Table 2 ). The standard is based on the observation of Stantech COGENT (Santos, et al., 1997), where the results of coconut morphology observation are International guidelines relating to the diversity of coconut germplasm, and the utilization of observation data as the basis for selection in plant breeding coconut.

In Table 2 it can be seen that generally the form of palm crowns in Lampanah tall is spherical and semi-spherical, which means that the more number of leaves produce a number of bunches and fruits. Each single leaf appear likely to produce one bunch of coconut. The results showed that the average number of leaves at Lampanah Tall coconut is 31 leaves/crown, and quite uniform among the MAS, which is indicated by the value of diversity coefficient $9.13 \%$ or less than $20 \%$. Number of leaves found in Mapanget Tall-OP, Mapanget Tall-S3 and Mapanget Tall-S4 were 23 leaves/crown, 26 leaves/crown and 26 leaves/crown respectively. The Mapanget Tall produces less leaves than Lampanah Tall. The length of 11 leaf scars shown that it is $91.10 \mathrm{~cm}$ for Lampanah Tall, thus shorter than the three generations of Mapanget Tall, which are $113.0 \mathrm{~cm}, 100.45 \mathrm{~cm}$ and $94.08 \mathrm{~cm}$ respectively (Mahayu and Novarianto, 2014). The girth measurement at 20 $\mathrm{cm}$ above soil level recorded an average of $165.73 \mathrm{~cm}$ and girth measurement at $1.5 \mathrm{~m}$ height is about $103.53 \mathrm{~cm}$. That means Lampanah tall coconut have 'Bole' (a large trunk at bottom) which is one of the main character 
Tabel 1. Average, standard deviation, and coefficient variance of production data and fruit components of Lampanah Tall coconut high yielding block

\begin{tabular}{|l|c|c|c|}
\hline \multicolumn{1}{|c|}{ Characters } & Average & SD & CV (\%) \\
\hline Number of bunches/palm (nuts) & 13.23 & 1.25 & 9.45 \\
Number of fruits/bunches (nuts) & 8.76 & 2.07 & 23.63 \\
Number of fruits/palm (nuts) & 117 & 3.48 & 30.32 \\
Weight of fruit (g) & 1,374 & 341.59 & 24.85 \\
Weight of husked fruit (g) & 900 & 238.76 & 26.52 \\
Weight of meat (g) & 419 & 98.12 & 23.39 \\
\hline
\end{tabular}

Note: $\mathrm{SD}=$ Standard deviation; $\mathrm{CV}=$ cooefficient of variance

Table 2. Average, standard deviation, and coefficient variance of morphological data, generative, and production component of Lampanah Tall coconut, Aceh Besar Regent, Aceh Province

\begin{tabular}{|l|l|c|c|c|}
\hline No. & \multicolumn{1}{|c|}{ Characters } & Average & SD & CV (\%) \\
\hline 1 & Crown shape & S and SS & - & - \\
2 & Number of leaves & 30.97 & 2.83 & 9.13 \\
3 & Stem Girth at 20 cm (cm) & 165.73 & 8.49 & 5.12 \\
4 & Stem Girth at 1.5 m (cm) & 103.53 & 12.73 & 12.29 \\
5 & Length of 11 leaf scars (cm) & 91.10 & 21.21 & 23.29 \\
6 & Colour of petiole & Green & - & - \\
7 & Length of petiole (cm) & 124.97 & 1.41 & 1.13 \\
8 & Length of rachis (cm) & 388.97 & 4.95 & 1.27 \\
9 & Width of petiole (cm) & 7.43 & 0.14 & 1.90 \\
10 & Thickness of petiole (cm) & 2.86 & 0 & 0 \\
11 & Number of leaflets (cm) & 123.50 & 8.49 & 6.87 \\
12 & Length of leaflet (cm) & 121.17 & 4.24 & 3.50 \\
13 & Width of leaflet (cm) & 5.25 & 0 & 0 \\
14 & Number of bunches (pieces) & 13.29 & 1.41 & 11.34 \\
15 & Length of bunch (cm) & 49.63 & 0.71 & 1.42 \\
16 & Width of stalk bunch (cm) & 4.04 & 0.07 & 1.75 \\
17 & Thickness of stalk bunch (cm) & 2.50 & 0.14 & 5.66 \\
18 & Length of flower arrangements (cm) & 39.10 & 7.78 & 19.89 \\
19 & Number of spikelet (pieces) & 40.07 & 2.83 & 7.06 \\
20 & Number of female flower (pieces) & 31.57 & 0.71 & 3.24 \\
21 & Fruit color & G,YG,BG & - & - \\
22 & Polar girth of fruits (cm) & 63.93 & 9.90 & 6.12 \\
23 & Equatorial girth of fruits (cm) & 57.72 & 3.54 & 6.12 \\
24 & Polar girth of husked fruit (cm) & 40.59 & 5.66 & 13.94 \\
25 & Equatorial girth of husked fruit (cm) & 39.10 & 2.12 & 5.42 \\
26 & Fruit shape & R, ES, E & - & - \\
27 & Husked fruit shape & $\mathrm{R}$ & & \\
\hline
\end{tabular}

Note: Leaf crown: $\mathrm{S}=$ Spherical, $\mathrm{SS}=$ Hemisperic (Semi-Spherical); Fruits color: $\mathrm{G}=$ green, $\mathrm{YG}=$ yellowish green, and $\mathrm{BG}=$ brownish green; Bentuk buah: $\mathrm{R}=$ Round, $\mathrm{ES}=\mathrm{Egg}-$ Shaped, E = Elliptic; dan Bentuk Biji: $\mathrm{R}=$ Round. 
traits of tall coconut types. Other characteristic from Lampanah Tall coconut is the length of stem of 11 leaf scars is $91.10 \mathrm{~cm}$. The length is still shorter than the Mapanget Tall varieties which has a length of approximately $118 \mathrm{~cm}$ for 11 leaf scars (Ditjenbun, 2014). The coefficient of variance $(\mathrm{CV})$ for the character trait, length of 11 leaf scars obtained $23.29 \%$, showing the diversity of the tree is quite large with a standard deviation value of $21.21 \mathrm{~cm}$. This means that with the selection of the length of 11 leaf scars on Lampanah Tall coconut, it can be directed to produce derivatives with closely leaf scars and coconut trees do not quickly become high.

Furthermore, it can be seen that all of the petiole has green color $(\mathrm{G})$, length of petiole 125 $\mathrm{cm}$, length of rachis $363.97 \mathrm{~cm}$, width of petiole $7.43 \mathrm{~cm}$, thickness of petiole $2.86 \mathrm{~cm}$, number of leaflets 124 pieces per half part of the rachis, length of leaflets $121 \mathrm{~cm}$ and width of leaflets $5.25 \mathrm{~cm}$. All characters of the coconut leaves of Lampanah tall coconut is fairly uniform, with a small standard deviation and all $\mathrm{CV}$ under $7 \%$. With CV less than 20, it is estimated that the character has small variation. Selection for improvement will not have much effect genetically.

Characteristics of bunches and inflorescence of Lampanah Tall coconut in Table 2 , shows that the mean number of bunches/ palm/ year was 13.29. The production of bunches is quite normal, because Tall coconut type in general will produce one leaf each month and on each axillary will appear one bunch of fruit. Further characteristics noticed in inflorescence of Lampanah Tall coconut are length of bunch is about $49.63 \mathrm{~cm}$, width of stalk bunch $4.04 \mathrm{~cm}$, thickness of stalk bunches 2.50 $\mathrm{cm}$ and length of flower arrangements 39.10 $\mathrm{cm}$. In coconut, the selection is directed to short stalk of bunch which is wide and thick in order to be strong enough to sustain fruits untill they reach the physiological maturity stage. In many instances it has been noticed in coconut hybrid that on early production, bunch stalks have broken when fruits were at 6-8 months old stage since it could not withstand the heavy load of fruit, especially if the number of fruit is already above 10 nuts per bunch(Mahmud, Novarianto and Rompas, 1990). The results of the analysis of the coefficient of variance $(\mathrm{CV})$ of bunches of flower of Lampanah Tall coconut indicate that they have a small diversity of flowers between palms, so the selection will not have much effect on derivatives. Further it was found that the average number of spikelet is 40 pieces /bunch, and the number of female flowers is 31.57 pieces. In general, about $30 \%$ of the female flowers in one bunch will develop normally and mature physiologically to the fruit after fertilization(Thampan, 1980). So from the average number of female flowers of Lampanah Tall coconut which totals to 31.57 flowers, the average number of fruits that can be obtained is about 9 nuts/bunch.

The results of morphological observations in Lampanah Tall coconut showed varying colors namely green (HG), green-yellow (HKGY) and a brownish green (HCBG). The observation of polar girth of fruit showed an average of $63.93 \mathrm{~cm}$ while the equator girth of fruit averaged at 57.72. Polar girth of dehusked nut was $40.59 \mathrm{~cm}$ and equatorial girth of dehusked nut was $39.10 \mathrm{~cm}$. A visual observation of the coconut showed that they are generally spherical. Coconut fruit in general have polar girth greater than equator girth in fruits with an egg-shape and elliptic.

\section{Fruit Component Variability of Lampanah Tall}

The observation of the weight components of Lampanah Tall coconut taken during 20142016 is presented in Table 3. The weight of the fruit component measured included whole fruit weight, nut weight, weight of split nut, the weight of husk, fruit water weight, shell weight, the weight of the nut meat and thick of nut meat. The average weight of the whole fruit was 1.525 $\mathrm{kg} /$ fruit and the highest was recorded in 2016 at $1.630 \mathrm{~kg}$ nut weight. The weight of the nut is an average of $969 \mathrm{~g} /$ nut and the highest was recorded in 2014 weighing $992 \mathrm{~g}$. Weight of split nut recorded an average of $672 \mathrm{~g} / \mathrm{nut}$, and the heaviest weight of $710 \mathrm{~g}$ was recorded in 2015 . There was more diversity in husk weight ranging from $498 \mathrm{~g}$ to $727 \mathrm{~g}$ per fruit, with an average of around $636 \mathrm{~g} /$ fruit. Weight of coconut water in 
Table 3. Average fruit component traits of Lampanah Tall coconut

\begin{tabular}{|l|l|c|c|c|c|}
\hline \multirow{2}{*}{ No. } & \multicolumn{1}{|c|}{ Characters } & \multicolumn{3}{c|}{ Average values of fruit components } \\
\cline { 3 - 6 } & & 2014 & 2015 & 2016 & Average \\
\hline 1 & Weight of fruit (kg) & 1.490 & 1.454 & 1.630 & 1.525 \\
2 & Weight of husked fruit (g) & 992 & 965 & 949 & 969 \\
3 & Weight of husked fruit without water (g) & 638 & 710 & 667 & 672 \\
4 & Weight of husk (g) & 498 & 727 & 682 & 636 \\
5 & Weight of coconut water (g) & 292 & 311 & 282 & 295 \\
6 & Weight of shell (g) & 223 & 243 & 222 & 229 \\
7 & Weight of endosperm $(\mathrm{g})$ & 459 & 442 & 445 & 449 \\
8 & Thick of endosperm $(\mathrm{cm})$ & 1.32 & 1.29 & 1.26 & 1.29 \\
\hline
\end{tabular}

Table 4. Potential production of copra base on average number of bunches, fruits and weight of endosperm Lampanah Tall coconut 2014-2016

\begin{tabular}{|c|c|c|c|c|c|}
\hline \multirow{2}{*}{ No. } & \multirow{2}{*}{ Characters } & \multicolumn{4}{|c|}{ Year } \\
\hline & & 2014 & 2015 & 2016 & Average \\
\hline 1 & Number of bunches/palm/year (nut) & 13.42 & 12.83 & 13.80 & 13.35 \\
\hline 2 & Number of fruits/bunch (nut) & 9.05 & 9.87 & 8.83 & 9.25 \\
\hline 3 & Number of fruits/palm/year (nut) & 119 & 174 & 122 & 138 \\
\hline 4 & Weight of endosperm/nut (g) & 459.47 & 442.50 & 445.50 & 449 \\
\hline 5 & Weight of copra/nut (g) & 229 & 221 & 223 & 224 \\
\hline 6 & Production of copra/palm/year $\left.(\mathrm{kg})^{*}\right)$ & 27.25 & 38.45 & 27.21 & 30.91 \\
\hline 7 & Production of copra/ha/year (ton) $\left.{ }^{* *}\right)$ & 3.35 & 4.73 & 3.35 & 3.80 \\
\hline
\end{tabular}

Note: *) Weight of copra is $50 \%$ weight of fresh endosperm

**) Production of copra per hectare with the palms spacing 9 x 9 meters. If this Lampanah variety planted in another areal, and the estimated production of copra like up table. 
Lampanah Tall averaged at $295 \mathrm{~g}$ and the weight of shell was observed to be approximately 229 $\mathrm{g} /$ nut. The most important component of the coconut fruit is the endosperm or meat. The results showed that the average weight of meat is $449 \mathrm{~g} /$ nut and it varies between 442 $\mathrm{g}$ to $459 \mathrm{~g}$. Weight of nut meat is considered as a criteria since meat weight above 400 $\mathrm{g} /$ nut is considered as good nut meat in coconut breeding. The weight of meat is the important component character of coconut palm, because it is used as the raw material for other products such as copra, coconut oil, virgin coconut oil, desiccated coconut etc. The results of the research on 28 accessions of Tall coconut in Mapanget Germplasm recorded the highest weight of meat in Bali Tall, Mamuaya Tall and Kinabuhutan Tall at $543.5 \mathrm{~g}, 508.0 \mathrm{~g}$ and $504.3 \mathrm{~g}$ respectively. Others which recorded high meat weight are Sea Tall, Mapanget Tall-83, Talise Tall and Mapanget Tall-2 with weight ranging between 436-460 g/nut (Novarianto et al., 2014).

Observation of production components included the estimated production of copra from Lampanah Tall coconut for three years, ie from 2014 to 2016 which is presented in Table 4. It can be seen that the observations of all characters which contributes to the production of copra showed values above the average of superior coconut for three year, ie. 2014 to 2016. Character like number of bunches/palm was recorded at 12.83 to 13.80 bunches, with an average of 13.35 bunches for the three years period or over 12 bunches/palm.

Number of fruits/bunch recorded an average of 9.25 nuts/bunch, which is above the minimum requirement at 7 nuts/bunch. Average production of 138 nuts/palm/year is also above the production of superior coconut at above 80 nuts/palm/year. Good coconut is described as one with an endosperm that weighs at least $400 \mathrm{~g}$ so that at least 5 coconuts will yield $1 \mathrm{~kg}$ of copra. In Lampanah coconut, it was observed that fresh coconut meat weight is $449 \mathrm{~g} / \mathrm{nut}$ which is already above the minimum requirement. On analysis of the components of production it is estimated that can be analyzed and estimated that approximately $224 \mathrm{~g}$ copra /nut of quality copra could be produced at water content of $50 \%$ (a minimum of $50 \%$ x $449 \mathrm{~g}$ fresh coconut meat). Average production of copra is 138 nuts x $224 \mathrm{~g}=30.91 \mathrm{~kg} / \mathrm{palm} /$ year. Over a ten year period of evaluation from the germplasm collection at United Plantations Berhad, various tall materials were evaluated and only the Tagnanan Tall and West African Tall had higher nut number. Tagnanan Tall recorded a yield of 135.9 nuts/palm/year and West African Tall recorded 132.1 nuts/palm/year which is higher than Malayan Tall at 123.8 nuts/palm/year, Laguna Tall at 118.6 nuts/palm/year, Tahitian Tall at 117.8 nuts/palm/year and Rennel Tall at 100.2 nuts/palm/year (Arulandoo, et al., 2014). The Bido coconut from Morotai island, North Maluku Province, Indonesia had a production as much as 124 nuts/palm/year, and other superior coconut varieties recorded production between 75-104 nuts/palm/year (Novarianto et al., 2016). Planting distance of Lampanah Tall coconut in the village of Ujong Keupula, Seilimeun district, Aceh Besar Regent are 8 × 8 meters or about 156 $\mathrm{palm} / \mathrm{ha}$ (Note : This is actual distance in farmer field). Lampanah Tall coconut production estimates for derivatives that take superior seed from the MAS, and planted with spacing $9 \times 9$ meters (Note : depends on the owner's decision to use spacing $9 \times 9$ meter square) or about 123 palms /ha will result in a production of 123 palms x $30.91 \mathrm{~kg}=3.80$ tons of copra /ha / year. The potential production of copra are high, because it is above the average national production at $1.1 \mathrm{ton} / \mathrm{ha}$ and exceed the requirements of HYB coconut at above 2 ton /ha. So it has potential as a superior coconut because production potential is greater than 3.0 ton ha / year.

Indonesia had reported that in 2016 there was a coconut crisis because coconut production in most of the provinces and regencies had decreased by $30-50 \%$, due to the effects of $\mathrm{El}$ Nino in 2015. But observations showed that production of fruit in Lampanah Tall coconut in Aceh Besar regency was not affected. This could 
happen because of the possibility that ground water in Lampanah was still quite available and shallow, and Lampanah tall coconut grew near and in and along the beach overlooking the Indian Ocean.

Observations on Lampanah Tall coconut compared with coconut varieties that have been released previously in the same location could not be done since Aceh province had no other coconut varieties as a comparison(Note: There was no control released variety near Lampanah tall). However, to study the extent to which differences occurred in some characteristics like oil production of Lampanah tall, a comparison with some Tall coconut varieties from other provinces with slightly different agroclimate was undertaken (Table 5).

In Table 5 it can be seen that for the character, length of 11 leaf scars, Lampanah Tall coconut has a length of $91 \mathrm{~cm}$, while the other Tall coconut varieties recorded values more than $100 \mathrm{~cm}$, such as: Mapanget Tall from North Sulawesi Province $118 \mathrm{~cm}$, Bali Tall from Bali Province $109 \mathrm{~cm}$, Palu Tall from Central Sulawesi Province $125 \mathrm{~cm}$ and Sawarna Tall from West Java $116 \mathrm{~cm}$. This means Lampanah tall coconut is found to show somewhat slower growth in height in comparison with the other Tall coconut varieties of the same age. While Lubukpakam Tall coconut from North Sumatra has a length of 11 leaf scar at about $91 \mathrm{~cm}$, Kramat Tall from Gorontalo Province recorded about $93 \mathrm{~cm}$, which is almost the same as Lampanah Tall coconut. The character of number of bunches did not show much difference and recorded about 13-14 bunches $/$ palm/year. The production of Lampanah Tall turned out to be high at about 138 nuts/palm/year, compared to the other 11 Tall coconut varieties which recorded production in the range of 75-102 nuts/palm/ year. Similarly, the estimated production of copra from Lampanah Tall recorded 3.7 tons/ ha/year compared to the other Tall coconut varieties which recorded approximately 2.5-3.5 tons/ha/year. Fat content of Lampanah Tall $(66.40 \%)$ was higher than Mapanget Tall (62.95\%), Lubuk Pakam Tall (59.96\%), Jepara Tall (61.95\%), Banyuwangi Tall (62.96\%), was on par with Bali Tall coconut, Sawarna Tall, Kramat Tall, and lower than Tenga Tall (69.31\%), Palu Tall (69.28\%) and Bojong Bulat Tall $(68.50 \%)$.

\section{Result of Fat Content and Fatty Acid Content Analysis}

Analysis of fats and fatty acids of coconut oil is done by taking the meat of Lampanah Tall coconut. The nutrient content including fat content and fatty acids are analysed. The main objective of coconut breeding program in Indonesia (Novarianto et al., 1998) is to produce plant material that has the character of high copra and early bearing. Besides that, other desired characters that can be combined in genepool are high copra oil content, resistance to bud rot and premature nut fall, tidal land tolerance, drought tolerance, high lauric acid content in oil $(\mathrm{C} 12)$ and high protein content on endosperm.

In Table 6, the results of the analysis of the fat content of Lampanah Tall coconut recorded a fat content of about $66.40 \%$. This result is very high, because some superior varieties such as Mapanget Tall coconut, Tenga Tall, Bali Tall, Palu Tall, coconut hybrid PB121, MAWA and KHINA-1 reportedly has a fat content of about $65-66 \%$. The water content of copra is recorded at around $3.42 \%$ and protein content at about $6.81 \%$. Endosperm of Lampanah Tall is found to contain high protein, so it is good for health if consumed both as a vegetable oil or tender coconut.

The results of the analysis of the fatty acid composition of Lampanah Tall coconut recorded as many as eight different types of saturated fatty acids and three kinds of unsaturated fatty acids. Total saturated fatty acids is approximately $94.27 \%$ and unsaturated fatty acids or those with a double bond at $5.72 \%$. Although Lampanah Tall coconut contains highest amount of saturated fatty acids, the kinds of saturated fatty acids that was highest was medium chain fatty acids, namely the lauric acid (C12) amounted to $46.50 \%$, capric acid (C10) at $10.16 \%$, caprylic acid (C8) at $9.49 \%$, and caproat acid at $1.06 \%$. Total medium chain saturated fatty acids is $67.21 \%$. Coconut oil contains medium chain 
Table 5. Comparison some production characters Lampanah Tall coconut with the other Tall coconut varieties

\begin{tabular}{|c|c|c|c|c|c|c|}
\hline \multirow[b]{2}{*}{ Varieties } & \multicolumn{5}{|c|}{ Characteristic } & \multirow[b]{2}{*}{$\begin{array}{l}\text { Oil content } \\
(\%)\end{array}$} \\
\hline & Origin & $\begin{array}{l}\text { Length of } \\
11 \text { leaf } \\
\text { scars }(\mathrm{cm})\end{array}$ & $\begin{array}{l}\text { Number of } \\
\text { bunches/ } \\
\text { palm/year } \\
\text { (nut) }\end{array}$ & $\begin{array}{c}\text { Number } \\
\text { of fruits/ } \\
\text { palm/year } \\
\text { (nut) }\end{array}$ & $\begin{array}{c}\text { Copra/ } \\
\text { ha/year } \\
\text { (ton) }\end{array}$ & \\
\hline Lampanah Tall & Aceh & 91 & 13 & 138 & 3.7 & 66.40 \\
\hline Mapanget Tall & North Sulawesi & 118 & 13 & 90 & 3.3 & 62.95 \\
\hline Tenga Tall & North Sulawesi & 104 & 13 & 75 & 3.0 & 69.31 \\
\hline Bali Tall & Bali & 109 & 13 & 75 & 3.0 & 65.52 \\
\hline Palu Tall & Central Java & 125 & 13 & 75 & 2.8 & 69.28 \\
\hline Sawarna Tall & West Java & 116 & 14 & 75 & 3.5 & 66.26 \\
\hline Lubuk Pakam Tall & North Sumatera & 91 & 14 & 75 & 2.7 & 59.96 \\
\hline Jepara Tall & Central Java & 111 & 13 & 80 & 2.63 & 61.95 \\
\hline Kramat Tall & Gorontalo & 93 & 13 & 102 & 2.8 & 65.00 \\
\hline Adonara Tall & $\begin{array}{c}\text { East Nusa } \\
\text { Tenggara }\end{array}$ & 114 & 13 & 94 & 3.0 & 66.83 \\
\hline Banyuwangi Tall & East Java & 122 & 14 & 75 & 2.6 & 62.96 \\
\hline Bojong Bulat Tall & Yogyakarta & - & 12 & 95 & 2.5 & 68.50 \\
\hline
\end{tabular}

Table 6. Level and fat contents, fatty acid, water, and protein from Lampanah Tall coconut copra

\begin{tabular}{|l|c|c|c|}
\hline \multicolumn{1}{|c|}{ Parameter } & Unit & Result & Test Methode/Technique \\
\hline Water & $\%$ & 3.42 & SNI.01-2891-1992, butir 5.1 \\
\hline Protein (Nx6.25) & $\%$ & 6.81 & SNI.01-2891-1992, butir 7.1 \\
\hline Fat & $\%$ & 66.40 & SNI.01-2891-1992, butir 8.2 \\
\hline Fatty Acid composition & & & GC (MU/INST/1) \\
\hline Saturated fat & $\%$ & 0 & \\
Butirat (C4) & $\%$ & 1.06 & \\
Caproat Acid (C6) & $\%$ & 9.49 & \\
Caprylic acid (C8) & $\%$ & 10.16 & \\
Capric acid (C10) & $\%$ & 46.50 & \\
Lauric acid (C12) & $\%$ & 16.43 & \\
Miristic acid (C14:0) & $\%$ & 8.10 & \\
Palmitic acid (C16:0) & $\%$ & 2.53 & GC (MU/INST/1) \\
Stearic acid (C18:0) & & & \\
\hline Unsaturated fat & $\%$ & 3.62 & \\
Oleic acid (C18:1) & $\%$ & 2.04 & \\
Linoleic acid (C18:2) & & 0.06 & \\
Linolenic acid (C18:3) & & & \\
\hline
\end{tabular}


fatty acid upto 61.93\% (Karouw, et al., 2013; Karouw and Santosa, 2014).

The most important fatty acid in coconut oil is lauric acid and Lampanah Tall coconut contains $46.50 \%$ lauric acid. It is higher that the APCC minimum standards for VCO at $43 \%$. The results of recent research suggests that excessive consumption of cooking oils containing trans fatty acids are very dangerous. Oils containing high unsaturated fatty acids, if used for repeated frying form a trans fatty acid. Coconut oil is rich in saturated fatty acids up to $90 \%$ and hence has lesser opportunity to form trans fatty acids, so it is more healthy to consumed. Coconut derived products which are now more popular are the medium chain fatty acids or MCFA (mainly lauric acid). MCFA is used for the treatment of Alzheimer's in the elderly and patients with impaired absorption. Coconut oil is rich in saturated fatty acids that are very stable against oxidation. Thus, coconut oil is able to inhibit the aging of body cells. Based on laboratory test results, Lampanah Tall coconut contains compounds needed for human health, ie a total of saturated fatty acids at $94.27 \%$, medium chain saturated fatty acids at $67.21 \%$ and lauric acid content $46.50 \%$.

\section{Conclusions and Recommedations}

Lampanah Tall coconut morphology ranging from the crown of leaves, stems, inflorescence and fruits in general is quite uniform. Analysis of the 23 quantitative character data showed a CV value below 20\% except the character length of 11 leaf scars which recorded a value of $23.29 \%$. The polar girth of Lampanah Tall coconut was generally longer than the equatorial girth, fruit shape classified as round shape, egg-shaped and elliptic. Lampanah Tall dehusked nut was generally round shaped(round). The Lampanah Tall coconut had the number of bunches at $13.35 /$ palm and the number of fruits at 9.15 nut/bunch, or an average of $138 \mathrm{nut} / \mathrm{palm} /$ year. Fresh coconut meat weight is $449 \mathrm{~g} / \mathrm{nut}$, or approximately $224 \mathrm{~g}$ copra/nut, and the potential for copra production was $30.97 \mathrm{~kg} / \mathrm{palm} / \mathrm{year}$, or 3.80 tons of copra /ha/ year. The Lampanah Tall coconut had a fat content of $66.40 \%$, the water content of copra approximately $3.42 \%$ and approximately $6.81 \%$ protein. Total $94.27 \%$ saturated fatty acids, medium chain saturated fatty acids $67.21 \%$, and $46.50 \%$ lauric acid content. The Lampanah Tall coconut is recommended as one of the resources of seednuts to be ised in replanting and rejuvenation of coconut palm in Aceh Province.

\section{Acknowledgement}

The authors want to express their acknowledgement for the collaboration and funding support from Agriculture Estate Crops of Aceh Province, and support staffs and technical staff in the observation and documentation of the coconut data gathered in the field. The authors appreciated and thanked the support given by Agriculture Estate Crops of Aceh Besar Regent. Authors wish to express their gratitude to the Director of Indonesian Palma Crops Research Institute for giving responsibility of undertaking this research in Aceh Province.

\section{References}

Akuba, R., M.M.M. Rumokoi, Miftahorachaman dan T. Rompas. 1997. Pengaruh curah hujan pada komponen buah kelapa. Jurnal Penelitian Kelapa 7 (2): 40-52.

Arulandoo, Xaviar, K. Sritharan, and M. Subramaniam. 2014. Performance of coconut hybrids in United Plantation Berhard and Commercial of seednuts. Cord Journal. 30(2): 41-50.

Direktorat Jenderal Perkebunan. 2014. Buku Statistik Perkebunan. Ditjenbun, Kementerian Pertanian. Jakarta.

Liyanage, D.V. 1973. Pemuliaan galur-galur kelapa berproduksi tinggi. Pemb. LPTI. 15-16: 23-27.

Karouw, S., Suparmo, Hastuti, P. Dan Utami. 2013. Sintesis ester metil rantai medium dari minyak kelapa dengan cara metanolisis kimiawi. Agritek. 33(2): 182188.

Karouw, S., dan B. Santosa. 2014. Minyak kelapa sebagai sumber asam lemak rantai 
medium. Prosiding Konferensi Nasional Kelapa VIII, Jambi, 21-22 Mei 2014. Hal. 73-78.

Mahmud, Z., H. Novarianto dan T. Rompas. 1990. Penyebab patah tandan muda kelapa hibrida KHINA dan penanggulangannya. Jurnal Penelitian Kelapa. 4(2):24-26.

Mahayu, Weda Makarti and H. Novarianto. 2014. Characteristic of Mapanget Tall selfed generation for coconut parent selection as pollen source. Buletin Palma. 15(1): 24-32.

Novarianto, H., T. Rompas and S.N. Darwis. 1998. Coconut breeding programme in Indonesia. Pp.28-41 in Coconut Breeding Proceeding. Paper presented at a Workshop on Standardization of Coconut Breeding Research Techniques, 20-25 June 1994, Port Bouet, Cote de Ivoire (P.A. Batugal and V. Ramanatha Rao, editors), IPGRI-APO, Serdang Malaysia.

Novarianto, H. and E.T. Tenda. 2002. Persiapan pelepasan lima varietas kelapa Dalam. Warta Penelitian dan
Pengembangan Tanaman Industri. 8(1): 911.

Novarianto, H., M.A. Tulalo and E. Karmawati. 2014. Sumber daya genetik kelapa: Status Pengelolaan dan Pemanfaatan in: Buku Sumber Daya Genetik Pertanian Indonesia. P.233-253. Badan Penelitian dan Pengembangan Pertanian. Kementerian Pertanian.

Novarianto, H., B. Santosa, M.A. Tulalo, S. Mawardi and I. Maskromo. 2016. Coconut varietal improvement in Indonesia. Cocoinfo International. 23(2): 34-38.

Romano. 2013. Potensi produksi dan kinerja industry pengolahan kelapa terpadu di Provinsi Aceh. Agrisep. 14(1): 1-9.

Santos, G.A., P.A. Batugal, A. Othman, L. Baudouin and J.P. Labouisse. 1997. Manual on standardized research techniques in coconut breeding. IPGRI, Selangor-Malaysia. p.35.

Thampan, P.K. 1980. Handbook of coconut palm. Kasaragod, India. 